"I just tell the bloody truth, as I see it": James Kelman's A Disaffection, the Enlightenment, Romanticism and Melancholy Knowledge

\title{
Aaron Kelly
}

\section{(2) OpenEdition}

\section{Journals}

Electronic version

URL: https://journals.openedition.org/etudesecossaises/193

DOI: 10.4000/etudesecossaises. 193

ISSN: 1969-6337

\section{Publisher}

UGA Éditions/Université Grenoble Alpes

\section{Printed version}

Date of publication: 30 April 2009

Number of pages: $79-99$

ISBN: 978-2-84310-138-0

ISSN: 1240-1439

\section{Electronic reference}

Aaron Kelly, "'I I just tell the bloody truth, as I see it": James Kelman's A Disaffection, the Enlightenment Romanticism and Melancholy Knowledge", Études écossaises [Online], 12 | 2009, Online since 30 April 2010, connection on 11 April 2023. URL: http://journals.openedition.org/etudesecossaises/193 ; DOl: https://doi.org/10.4000/etudesecossaises. 193 


\section{"I just tell the bloody truth, as I see it": James Kelman's A Disaffection, the Enlightenment, Romanticism and Melancholy Knowledge}

The assertion by the troubled teacher Patrick Doyle - "I just tell the bloody truth, as I see it" (p. 112) - in James Kelman's novel A Disaffection goes to the heart of Kelman's own aesthetic of showing things as they are. However, the qualifying clause - "as I see it" - also suggests that truth is not evidentially absolute and immediate but provisional or situated. Of course the very concept of truth would seem to require of itself a totalised fulfilment of its own promise. That is, truth should be completely and self-evidently verifiable as an absolute or else it begins to collapse into its opposites: falsity, fiction, imagination, discursive formation and so on. If truths are perceived or construed by differing subjects in variant ways then truth as such would appear to be merely a series of constructions which then lack the very thing which they would nominate: truth's unmediated actuality. Historically, it was the task of Enlightenment science and rationality to reconcile subject and object under the rubric of truth, to sustain mutually the secure certainty of both mind and world in reasoned acts of verification. But if the truth of the world is only ever and already a construction of the thinking subject then the truth of both instead becomes a fiction, a fallible imaginative mechanism. The order of reason, the science of fact, the law of objectivity are all reduced to the foundational myths of the thinking subject and its flawed and conjectural efforts to assert its own certainty. Such a proposition - that truth cannot realise its own absolute - has of course become the mainstay of what is considered the postmodern condition. From Michel Foucault's sense that knowledge is a production of power (and vice versa) to Jean-François Lyotard's account of the "crisis of metanarratives" which supported the Enlightenment ideals of truth, rationality, progress (and indeed, according to Lyotard, the reflection of those ideals in the teleological faith of Marxism and the Left), the 
postmodern has sought to undermine the ideological basis of objectivity in its scientific, social and historical terms. ${ }^{1}$ Worse still, truth is not only a conceptual antinomy, a semantic contradiction of abstract science; the current postmodern critique also accuses Enlightenment rationality of providing the myth of righteous objectivity by which systems of domination have legitimized themselves. In this sense, truth's only residual verity is the fact of its complicity in power.

This postmodern antipathy to Enlightenment values follows on, to a large degree, from perhaps the most famous critique of systemic reason in terms of modernity: Adorno and Horkheimer's 1944 opus, Dialectic of Enlightenment. There are, however, also some important divergences between Adorno and Horkheimer's critique from the standpoint of modernism and mass culture and postmodernism's anti-Enlightenment, especially in relation to notions of art and culture, which will be considered in due course since they bear directly upon the politics of Kelman's sense of truth and reality. The key aspect of Adorno and Horkheimer's attack is that Enlightenment science positioned itself as the overthrow of myth and superstition yet it became the very thing (myth) which it feigned to supplant. Which is to say, Enlightenment science effaced itself by becoming its own self-sustaining myth. Its instrumental rationality sought to systematize all things into an ordered totality yet it feared the limits of its own regime of truth. As Adorno and Horkheimer put it:

Man imagines himself free from fear when there is no longer anything unknown. That determines the course of enlightenment [...] Nothing at all may remain outside, because the mere idea of outsideness is the very source of fear. (p. 34)

Enlightenment is then transfigured from a project of uncovering reason and truth to an apparatus of totalitarian domination: it brutally imposes its regimes of reason and truth upon the world and either subordinates or obliterates anything which cannot be systematized and regulated within the terms of its own conceptual strictures. The horrors of the twentieth-century - in particular, the annihilation of what is other in the form of Nazism and the Holocaust - led Adorno and Horkheimer, and many subsequent thinkers, to regard the instrumental systematization of Enlightenment reason as culminating in the unreason of a

1. See Michel Foucault, Power/Knowledge: Selected Interviews and Other Writings 1972-1977, trans. Colin Gordon, John Mepham and Kate Soper, Brighton, Harvester Wheatsheaf, 1980; and JeanFrançois Lyotard, The Postmodern Condition: A Report on Knowledge, trans. Geoff Bennington and Brian Massumi, Manchester, Manchester U.P., 1988; and Jean-François Lyotard, The Differend: Phases in Dispute, trans. George Van Den Abbeele, Manchester, Manchester U.P., 1988. 
rationality that must know and dominate in equal measure and consequently exterminate all that remains intractable to it. So in pursuit of the same Enlightenment ideals of what is true and right, the objectivity of science and reason transforms into irrational barbarity. In Adorno and Horkheimer's words: "Enlightenment with every step becomes more deeply engulfed in mythology" (p. 12).

Hence, an apparently rigorous regime of scientific scrutiny and rational objectivity ends up occluding truth: "there is to be no mystery - which means, too, no wish to reveal mystery" (Adorno and Horkheimer, p. 5). Clearly, then, Enlightenment reason and the truths which it sustained have become increasingly strained across the last century and into the present one. However, if, more recently, the current canon of postmodern thought accuses the Enlightenment of propagating a regime of truth that only serves to dominate the world, to construct a truth incapable of acknowledging anything resistant to or outside of its instrumental ordering, then perhaps a circumspection is also necessary with regard to postmodernism's evaluation of truth as merely a production of power, of the narrative, conceptual order of domination's self-legitimation. For if, as alleged, Enlightenment truth would deny a voice or a stake in the world to all those who remain incommensurate with its self-image, then surely the postmodern position where there is no truth is not the subversion but the fulfilment of such an enterprise. To deny - universally and absolutely, it should be stated with some irony - the whole basis of truth as anything other than a fiction amongst fictions is also to further de-legitimate any project of resistance or emancipation which struggles to articulate the truth of ongoing suffering and injustice. Put another way, where the Enlightenment is critiqued for imposing a dominant truth which denies the truths of others, or alternative versions of truth, so too the postmodern proclamation that there is no truth achieves a similar end through exactly the inverse logic. For such a dispensation further impedes any effort to challenge its own dominant, absolute premise by denying the status of truth to any constituency who would offer alternatives to postmodernism's play of relativized discourses. In simple terms, where once the vanquished were instructed that their truths were false because the Enlightenment possessed the monopoly on truth, now the position is that such truths are untrue because there is no such thing as truth. Kelman's A Disaffection offers a different pathway across these fault lines and it arrives at what I will term a melancholy knowledge or truth. It is a melancholy knowledge in this novel because it mourns the loss of some pure truth uncontaminated by the instrumental domination of the Enlightenment's own concept and the horrors committed in the name of the latter. Yet $A$ Disaffection also yearns for the persistence of truth, for a 
critical engagement with the world, even as it acknowledges the fragmentary, fractious and provisional nature of that knowledge. A melancholy knowledge is still of form of knowing though it exists in a negative relation to truth: that is, it forgoes its place in some systemic absolute that has become domination's mythology but reiterates that truths must be known if the world is to be understood let alone changed for the better.

For oppressed groups - for those on the receiving end of history - the Enlightenment has always been a fractious and troubling inheritance or disinheritance. The Enlightenment promised progress, emancipation, reason, illumination and truth yet the world is still riven by poverty, suffering and oppression that dim the ideals of the former. Is it that the oppressed need more of the Enlightenment: that is, once Enlightenment values are properly universalized, when everyone is allowed to share them, will poverty and suffering then be banished? Or, is the world the way that it is precisely because the Enlightenment cannot be universalized? In other words, poverty and suffering persist because the Enlightenment's credos of reason, freedom and progress were never universals but the privileges enjoyed by some at the expense of the many. As such, truth, freedom or emancipation would have to be rethought so that they are not simultaneously grounded in their opposites. So is it the ongoing project of enlightened modernity to overcome finally the injustices and of the world or was such a project always the myth of an instrumental reason that accorded benefits to some at the same time that it also served to legitimize colonialism, slavery, the inequalities of class society and capitalism, world war and racial extermination programmes? If history's victors have always thwarted full emancipation then they should not also be allowed to monopolize or sully the very project and ideal of emancipation, for that would indeed be their final victory. My term, melancholy knowledge, therefore, is intended in this context to insist that there still be truths, even if the first awareness of such knowledge is that enlightened modernity has become the codeword for a barbarism conducted as reason. Melancholy knowledge is thus a truth troubled by its own name.

Kelman's A Disaffection is highly germane to debates about the damage done to truth and reason by the motors of history given that it is replete with allusions to Enlightenment thought and also to the Romanticism which functions as a critique of the former, emanating from the times of revolution and social turmoil in the late eighteenth century. In Patrick Doyle's desperate imagination, the heavyweights of German idealist philosophy, such as Hegel, or German Romanticism, such as Goethe and Hölderlin, are repeatedly invoked. In particular, Kelman's novel permits a rethinking of the role that art and culture might play in complicity with, or in opposition to, regimes of instrumental reason. In so doing, A Disaffection 
is instructive precisely because it is critical of the Enlightenment but also wary of the notion of a pure art of Romantic redemption uncontaminated by domination. It is this diagnostic analysis of Romanticism in Kelman's novel which sets it apart from the aesthetic utopianism of the latter day Romantics of postmodernism. Where postmodern thinkers such as Lyotard connect reason, truth and Enlightenment to a civilized monstrosity (and dismiss Marxism and other collective projects of emancipation as pandering to the same totalitarian or repressive rationality) it is, supposedly, only in art that some form of transcendence is possible, that some space might be found that is not bound by systemic power and social degradation. According to such a position, in a world where mechanised domination masquerades benignly in narratives of ethical improvement or scientific progress, where freedom is despoiled by the false choices of consumer capitalism, art offers itself as a experience of arresting, transcendent singularity. It is at this juncture, however, that such postmodern aesthetic utopianism can be distanced from Adorno's version of art in a way that bears directly upon $A$ Disaffection. To fully understand Adorno's theory of art, it is necessary to reclaim the Marxian strands of his thought rather than cast him as a detached aesthete in which guise he is then made to prepare the ground for the latter day Romanticism of the present which finds in literature a Sublime that escapes the supposed contamination of the social and political. Anyone such as Adorno, who can look down their nose at jazz music (of all the things to pick upon in the context of commodification!) has surely made snobbery - perhaps aptly enough - a fine art. But equally, Adorno's work provides a forceful methodology by which the politics of aesthetics in Kelman's fiction can be unfolded.

By way of establishing a disparity between Adorno's approach and that of the postmodern Sublime, Adorno did certainly grant art its own laws of formal autonomy, yet his account of the aesthetic also retains a negative relation to the world, to the social materiality out of which the artwork is made but to which it is not bound. Indeed art and its promises are troubled by the very inequalities of the world that they would resolve. Lyotard's postmodern Sublime, or what is now claimed as a New Aestheticism, proposes a very different order of aesthetic utopianism that would escape the mechanized rationality and standardized banality that characterize contemporary capitalism. ${ }^{2}$ Oddly though, in this admixture of idealism and Romanticism, such thought finds in literature a neoKantian Sublime which Kant himself located beyond literature or art.

2. For a lively, engaging collection of essays propounding a New Aestheticism, see John J. Joughin, and Simon Malpas (eds), The New Aestheticism, Manchester, Manchester U.P., 2003. 
Jacques Rancière has saliently identified the contradictions in Lyotard's effort to assert an aesthetic Sublime outwith the degradations of enlightened modernity by discerning how it conflates Kant's moral (and extraartistic) Sublime with Edmund Burke's poetic Sublime. ${ }^{3}$ So for today's Neo-Kantians or Neo-Romantics art is the repository of the Sublime. A deep irony emerges here too in the sense that Lyotard and others bemoan the totalizing domination of the world by an instrumental reason yet they end up constructing their own absolute, a "literary absolute" in the words of Phillippe Lacoue-Labarthe and Jean-Luc Nancy. ${ }^{4}$

This article will largely critique this postmodern Sublime or literary absolute in class terms with reference to Kelman's fiction, but it is also worth pointing out that a lot of the current aestheticism has a basis in Martin Heidegger. There have been numerous attempts to rehabilitate Heidegger, to engage in his de-Nazification if you like. Such efforts would make Heidegger's Nazism retractile where he himself never apologised. Most problematical for those who would defend or absolve Heidegger are his notorious Rectoral address at the University of Freiburg in 1933 and his An Introduction to Metaphysics (which reflects the sentiments of that address). ${ }^{5}$ In An Introduction to Metaphysics Heidegger praises what he terms the "greatness" and "inner truth" of Nazism. This work also conveys Heidegger's sense that it is only the German language which inherits the rightful descent from ancient Greek as the carrier of originary presence, spirit and unity that is then often conflated with soil, earth, blood. It is, according to Heidegger, the "historical mission" of Germany to rescue the "darkening world" and its "emasculation of spirit" (p. 45). Although Heidegger's defenders would construe such claims as unfortunate but pragmatic concessions to Nazi ideology as a means of preserving his career and status, it is not so easy to separate Heidegger's supposed token support for the Nazi regime from his wider work on the decayed nature of Being in a fallen world. For someone like Heidegger it is only in rare moments of art - especially his favoured writers such as Hölderlin - that there is a break in the continuum of time, an opening of some primordial Being beyond the contamination of modernity's mediocrity and alienation. ${ }^{6}$ Heidegger set himself the philosophical task

3. See Jacques Rancière, The Future of the Image, trans. Gregory Elliott, London, Verso, 2007, p. 109-142.

4. See Phillippe Lacoue-Labarthe and Jean-Luc Nancy, The Literary Absolute: The Theory of Literature in German Romanticism, trans. Philip Bernard and Cheryl Lester, Albany, State U. of New York P., 1988.

5. See Martin Heidegger, An Introduction to Metaphysics, trans. Ralph Manheim, New Haven, Yale U.P., 1959.

6. See Heidegger, Poetry, Language, Thought, trans. A. Hofstader, New York, Harper, 1971. 
of reaching such a clearing where Being opens up once more as pure promise, where in the midst of our modern distress the advent of the gods is upon us, a unity and oneness that Heidegger invests in the premodern. Notoriously of course, while waiting for the advent of the gods Heidegger decided that in the meantime a Fuhrer would suffice.

Obviously not all aesthetic purists are Nazis - far from it. But it is worth noting how Heidegger's version of a literature of pure promise permits a number of his defenders or inheritors to detach - or at least to attempt to detach - his politics from his aesthetics. More widely, then, it is worth remaining circumspect about any form of aestheticism which claims that its version of aesthetics finds an art beyond the political or indeed that it is in itself as a form a criticism beyond politics. So if Heidegger is an extreme case, there is a more general effort in the New Aestheticism or postmodern Sublime to assert that art not only offers our means of escape from the deprivations of the world but also that art is reduced by the crudity of politics. This new school of reworked idealism and Romanticism claims that the singularity of the artwork - the pure promise of its Sublime openings - is sullied by political or sociological abstraction whether this be in the form of Marxism, say, or identity politics where literature is produced or appreciated in terms of working-class community, for example, or African-American history, lesbian culture or decolonizing resistance in the Caribbean. Such contextual, political or social issues and identities get in the way, it is proposed, of the irreducible singularity of art's particularity, its aesthetic autonomy. And, perhaps unsurprisingly, Kelman's work has been attacked from precisely this perspective by Thomas Docherty, whose own preferred term for this kind of artistic Sublime is aesthetic democracy. According to Docherty, literature is a means by which the self becomes other rather than a space of selfratification. It is an experience of alterity or otherness so that identity is disrupted or made better and more generous by the sublime singularity of aesthetics. Any literature or reading of literature undertaken in terms of a politics of identity, Docherty claims, are gross reductions of aesthetic potentiality that ultimately fail to win the status of culture proper. Hence, for Docherty, the whole idea of a working-class culture lacks this capacity for and hospitality to otherness which demarcates the transformations of aesthetics. So Kelman becomes a target as an example of a literature that degrades this absolute hospitality. Docherty states his case as follows:

To put this in perhaps polemical terms, we have no culture (no hospitality) when we read an other that bears a name and a social status (for example, when we read, say, James Kelman for the sake of his identifications with or identifiability as "working-class Glaswegian"). In these readings, there is no 
hospitality, and as a consequence, no culture at all. I do not say, of course, that we do not read such writers. Rather, I argue that we seek a reading based in friendship or hospitality according to which I accept that I cannot know what it might mean to be an "authentic working-class Glaswegian", or a "black woman", or indeed any other category associated, in the end, with a politics of identity. A hospitable reading attends to singularity, on the grounds that anything else is both egocentric and inimical to culture, growth, Bildung. (p. 40)

In this interpretation, both Kelman in his "identifications" with working-class Glasgow or readings of his work that engage class politics are not really culture and literature at all. Docherty relates that he is sick of people reading as a particular identity: as a working-class Glaswegian, as a black lesbian, as an Irish nationalist, etc. Given Roland Barthes's account of the ex-nominating operation of bourgeois ideology - its capacity to un-name itself yet shape everything in a bourgeois society as apparently natural or self-evident - the notable absence from Docherty's weary, long litany of reductive identities is reading as a bourgeois. ${ }^{7}$ This aporia helps to introduce a class politics to this apparently generous account of an aesthetic democracy. For Docherty's major claim for aesthetic singularity is that it is the true place where democracy happens in a world governed by consumerism and standardized commodities and identities. Docherty posits that "it is in art and in aesthetics that we find a privileged site or a paradigm of the very potentiality of selfhood that establishes this democratic condition" (p. XVIII). There is something of liberal humanism in this aesthetic utopianism in the sense that if you are naive enough to take it on its own terms then it is very difficult to find anything much with which to disagree. However, again like liberal humanism, this aesthetic democracy fails to take into account the vast revolutionary transformations that would be necessary for its platitudes to be freely available to all. What is most contradictory and most telling in Docherty's above statement is his claim that art offers a privileged site in which democracy happens. Surely any democracy worthy of its own name cannot emanate from privilege.

Docherty's position - that acts of aesthetic appreciation by a privileged subject can escape the deprivations of capitalism - simply reworks the anxious call by Kant and others for a republic of the learned in the wake of the French Revolution and the shock that it is not only philosophers who can think about or transform the world. So too Docherty's aesthetic democracy reserves for a cultured elect any opposition to the

7. See Roland Barthes, Mythologies, trans. Annette Lavers, London, Vintage, 1993, p. 139. 
market and thus it not only denies the status of culture to any art which diverges from such aestheticism but also, politically, arrogates any possible resistance to capitalism (collective action, armed struggle and so on) other than the oxymoron of a privileged democracy of art. By making freedom the preserve of an aesthetic democracy, oppressed groups must collectively give up their own liberation, which is then renamed someone else's culture. But art is not so pure. And this is why the Marxist strands of Adorno's aesthetic are in need of reclamation. While Adorno advocated the formal autonomy of art he also insisted that it remained a part of the world to which it nonetheless resides negatively or critically. In contrast to Docherty's aesthetic democracy of pure freedom, Adorno's work instructs that culture exists precisely because what it promises does not. That is, the freedom and autonomy promised by art are not freely available to all but bought at the price of unfreedom and inequality. As Adorno argues: "All culture shares the guilt of society. It ekes out its existence only by virtue of injustice already perpetrated in the sphere of production." (Prisms, p. 26) So too, then, culture as Docherty and the New Aestheticism would define it exists precisely because freedom does not. In a world of inequality art is always complicit in what it would criticise, given the inequalities embedded in the making of both culture and society. So rather than moving us towards a universal freedom, such a privileged aesthetic democracy only serves to preserve a freedom chained to its own opposite.

Docherty's approach is also problematic in that he attacks what he perceives as a reductive notion of working-class culture in the same breath with which he harangues consumer capitalism as though it were the working class who were responsible for consumerism. If anyone is to blame for the dominance of neo-liberal economics and consumerism today it is obviously the bourgeoisie and bourgeois society - another moment of bourgeois ex-nomination in Docherty's manifesto - the very same bourgeois society which also regulates the definition of, and access to, art and culture. Hence, Docherty's neo-Romantic notion of a pure culture in opposition to society or consumerism collapses into that which it opposes: the fracture of bourgeois society. Contrastingly, Adorno and Horkheimer's critique of the Enlightenment refuses any neat division between mass culture and High culture, or culture and society more generally. Adorno and Horkheimer comment:

The purity of bourgeois art, which hypostasized itself as a world of freedom in contrast to what was happening in the material world, was from the beginning bought with the exclusion of the lower classes - with whose cause, the real universality, art keeps faith precisely by its freedom from the ends of the 
false universality. Serious art has been withheld from those for whom the hardship and oppression of life make a mockery of seriousness, and who must be glad if they can use time not spent at the production line just to keep going. Light art has been the shadow of autonomous art. It is the social bad conscience of serious art. The truth which the latter necessarily lacked because of its social premises gives the other the semblance of legitimacy. The division itself is the truth: it does at least express the negativity of the culture which the different spheres constitute. (p. 135)

In these terms Docherty's opposition of an aesthetic democracy to consumer culture forgets the implication of High culture in the same social processes which produce mass culture and inequality. Culture can only promise a democracy in whose forestalling culture is already mournfully implicated. There is a moment of transference in Docherty's thinking whereby his reductive homogenization of "working-class Glaswegian identity" actually functions to shore up an assured and assumed sense of "we", of the community of aesthetic subjects, so that an aesthetic democratic community is produced by the act of denying others the same potentiality, difference and heterogeneity. Thus, Docherty's privileged self becoming other than itself is the embodiment of a democracy that is in fact based on a reductive notion of other, lower selves denied the sophistication of the aesthetic polis. Given that the New Aestheticism calls for a renewed sense of aesthetic and formal particularity, a close engagement with form, it is worth pointing out that Docherty - in accusing Kelman of some homogeneous working-class Glaswegian identity - completely misreads the narrative register of Kelman's work and the processes of subjectivization therein. There is no settled narrative subject in A Disaffection or Kelman's other novels - whether at an individual, communal or narratorial level. Instead Kelman's work continually shifts its narrative mode between first, second and third person positions individually and collectively. "I", "ye", "you", "he", "one" all continually modify one another in Kelman's fiction in perpetual irresolution. At the level of content, Patrick Doyle's vocation as teacher in A Disaffection ensures that he is unreconciled with his own working-class background, but equally entails that working-class milieu is already fragmented and internally ruptured so that there is no reconciliation of the individual with society, or, for that matter, the individual with itself or society with itself. Additionally, Doyle's consciousness in A Disaffection is - at the level of form - conflicted against itself since it interminably shifts out of its own person while, from the opposite perspective, the third person narrative can only disclose its own limits and dissolution back into first and second person modes. There is no "one" who speaks for all in 
some consensual, superintending mode which relates Doyle's plight to the reader. At the same time, Doyle has no settled, homogeneous or resolved self which coheres in the form of character and narrative consciousness. Aptly, given that A Disaffection continually alludes to Hölderlin, Kelman's narrative technique is structurally close to the parataxis which Adorno discerned in the poetry of Hölderlin: that is, the disintegration of the subject position and the syntax of logic which normally enthrone and legitimize the subordination of the object to reason. Adorno writes of Hölderlin that "by shattering the symbolic unity of the work of art, he pointed up the untruth in any reconciliation of the general and the particular within an unreconciled reality" ("Parataxis", p. 127). Similarly, Kelman's character Patrick Doyle is perpetually paratactic in that his consciousness is impinged upon by a narrative voice which in turn is also discontinuous and provides no consensual commensurability between "I" or "he", the first and third person registers which harmonize the individual and society in the conventional novel.

Moreover, Docherty's account of some reductively homogenous notion of a Glaswegian working-class identity is completely out of step with Kelman's fierce strain of individualism that actually, if anything, bears traces of Docherty's own idealised neo-Romanticism. It is less that Kelman opposes some collective identity to the enlightened self or the transcendental "I" and more that Kelman's fiction ends up providing a critique of prevailing individualism by virtue of the fact that it believes in the individual so deeply but yet cannot universalise the promise of individual freedom in working-class contexts. Indeed, in Some Recent Attacks Kelman himself is keen to pitch his own work as attuned to the nuances of individual experience and existence and at the same time a concomitant freedom associated with that individual lens - in a rejection of more collective or communal identifications that are offered as reductive abstractions:

What actually is the proletariat? Or for that matter the bourgeoisie? How do you recognise a class of folk? Or a race of people? You recognise them by general characteristics. When we perceive a member of a class we are not perceiving an individual human being, we are perceiving an idea, an abstract entity, a generality; it is a way of looking that by and large is the very opposite of art. Artists should be able to look at what they do and know when it is not wrong, they need to value things for themselves - especially their own work. (p. 11)

Notably, such generalities are in fact deemed "the opposite of art". Art, therefore, is proposed as a distillation of particularity, of concrete, embedded truths which eschew generality and catchalls. However, 
Kelman also has to concede that people are oppressed in collective or communal forms and that they are misrepresented or underrepresented both politically and artistically:

$[\ldots]$ such groups of people wouldn't have been found in society. They are marginalised, confined below stairs, kept out of reach in a housing scheme, stuck in a closet, on a reservation, a homeland, a ghetto, an inner or outer city slum, whatever. And when you were standing there in some particular company, the servant or chap who carries the painting, you wouldn't be there, no one would "see" you, that concept of "invisibility" again. (p. 15)

So Kelman's own pseudo-Romantic creed of individualised artistic freedom and truth has to face the fact that such perspectives are socially mediated and that the disenfranchisement of people in collective forms ensures that such individualism is neither absolute nor fully realisable. It is in this sense that Kelman's work is instructive as to the limits of individualism - this aesthetic interrogation of individual subjectivity and consciousness - precisely because Kelman believes so fiercely in a libertarian notion of the individual. The critique resides - negatively - in the incapacity of Kelman's narratives to realise fully an individual freedom. This inability to implement the promise of individual freedom itself divulges that individualism is not such an individual matter after all. Instead, the individual is just as socially mediated as the proletariat or the bourgeoisie in the above passage from Kelman. Hence, it is important to ascertain how the governing concept of the individual actually helps structure the class inequalities of society rather than it standing defiantly outside such determinations. Kelman's inability to reconcile an individual with itself, to make the individual coincide with its own autonomy, demonstrates that the total freedom disbursed under the name of individualism is not universally possible. The liberty which capitalism offers as its ultimate outcome is rather the overlay of an ongoing unfreedom through which the freedom of the few continues to the cost of the many. As such, this failure in Kelman to make the individual absolutely individual returns us to its social basis in a capitalist society.

In a class society, the opposite of the declaration we are all not the same is not we are all different. Such a proposition passes off inequality as heterogeneity. Of course capitalism standardizes as much as it stratifies. There is honour in the scorn of prevailing platitudes and received opinions, especially in a world which manufactures consensus as the foreclosure of radical transformation. But the heroic pose of the bourgeois subject guarding its privileged autonomy from its object - a corrupting world collapses in on itself. The apparently self-sustaining monologue of this autonomous solitude is itself structurally and mutually dependent upon 
its own object which it must therefore then silence. And that object is the clamouring of collective, accumulated unfreedom and oppression. The self as private property is only conceivable in the forgetting of collective deprivation. The pervasive individualism of bourgeois society infers a free-thinking subject in masterful control of its object and immune from the contamination of that object - the social. Yet it is the toiling, disenfranchised hordes who are not the hindrance which the self-creating individual must transcend in achieving its freedom but instead the very basis for the production of that subject. For this reason, when the bourgeois individual would seek to make itself identical with its own autonomy it is therefore also haunted by its own social ground, by the object whose unreconciled injustices persist. Any uncritical hankering after individual freedom forgets the social mediation necessary for the freedom enjoyed by specific social classes: that is, the collective unfreedom and attenuation of individuality necessary for the ideology of freedom to permeate bourgeois society. In other words, a freedom deserving of its own name - a freedom freely open to all - is only possible through the overthrow of the very bourgeois, capitalist society that would arrogate freedom as one of its many monopolies.

So in Kelman's writing it is less that there is an abstract or metaphysical confrontation between the individual and the social, with the former a bastion of freedom fending off the encroaching, standardizing requisitions of the latter. It is more that the two collide. Most clearly, the contradictions of individualism not only inhere within bourgeois ideology but also when other social constituencies seek to avail of individual freedom. To be working-class is already to be cast as the object - the non-thought, the non-identical - of someone else's modes of subjectivity, to be bound by the unfreedom of a class system which liberates someone else. So when a working-class subject claims as its right the universal freedom enthroned by bourgeois individualism a stark antinomy occurs. The apparent universalism of bourgeois freedom falls in on itself in dialectical reversal which shows that the only absolute of such freedom is the unfreedom upon which it depends. Hence, in Kelman's narrative structures, terms such as stream of consciousness or interior monologue are inappropriate since there is no free-flowing subject able to coincide purely with itself and represent the world in its own terms, or even to withdraw into recasting the world in the private property of a subjective autonomy. Rather, there is a continual collision whereby differing registers of subject position antagonistically fail to reconcile themselves with one another or with a world that is itself unreconciled.

Undoubtedly, Kelman's narrative technique is very close to what became known as free indirect discourse and which is largely seen as a key 
component of Modernist fiction. Hugh Kenner's foyce's Voices is an exemplary shaping of what is now a critical common place about free indirect style in Modernist fiction: that is, the ability of an author to withdraw from the style of his or her narrative and to allow a character's consciousness to colour the tone and shape of what is still ostensibly a third person perspective. Kenner uses a passage involving the character Uncle Charles in A Portrait to illustrate this thesis: "The normally neutral narrative vocabulary pervaded by a little cloud of idioms which a character might use if he were managing the narrative." (p. 17). However, my own preferred term for Kelman's narrative strategy would be unfree direct discourse. Which is to say, you do not get an easy flow from narrator into character in A Disaffection but rather the collision of a narrative and a character that are not only heterogeneous and unreconciled to one another but also to themselves. No shared, overarching focalization is possible whereby the discourse may move freely across subject positions. There is only the direct impacting of discourses that are unfree or bounded by their situatedness in hierarchical registers of language and a society stratified by inequality. In this class context, there is no autonomous subjectivity in A Disaffection, or, more radically, any mediating discourse in the form of a superintending narrative form which consensually makes that subject agree its place in society.

Just as the social basis of the individual in A Disaffection rebuts Docherty's aesthetic democracy of a privileged subject becoming other with itself in contrast to the supposedly homogeneous identities provided by capitalism, so too Kelman's novel undermines the cultural means by which this apparent transformation of the self takes place, by returning art to its social implication. At one level, there again appears to be some common ground between Kelman and the New Aestheticism in that Doyle's happening upon a pair of discarded industrial pipes at the back of an arts centre and his subsequent transfiguration of them into musical instruments are all rendered in the language of a kind of singular, sublime event that defies representation: "It was really beautiful. Of a crazy sort of nostalgia that would aye be impossible to describe in words, and not in oils either." (p. 1) Where Doyle's profession as a teacher clearly links him to the co-option of culture and education by the state, there is nonetheless an underlying Romanticism in his desire that the pipes might offer an escape from all that, an art of pure promise that is still possible. He strives to keep the rationalizing legacy of the Enlightenment - his own "conceptualising" as he calls it - at bay by advancing an untainted spontaneity of the imagination with regard to the pipes which is evidently a Romantic need for transcendence of the social and of the conceptual ordering of things by reason. Doyle is continually troubled that his thinking about 
the pipes seems to defer interminably his material grasp of them. His decision to paint the pipes reflects self-critically on the production of a rational art, insofar as Doyle feels that his own attempt to make the pipes artistic or enhance them aesthetically actually distances him from their physical materiality. So too, at a philosophical level, Doyle fears that the whole conceptual framework of thought also ruins the truth of his discovery rather than deepening it. For example:

$[\ldots]$ and yet, this conceptualising. Creating a distance already. Only a couple of days since the first sounds and now here he was attempting to get away from it, from the actual physicality of them. That was hopeless. That was the kind of thing he always seemed to be doing nowadays. The totality of it: the totality of it; the way the sounds had been the other night, or was it last night, the way the actual sounds had been, that was it - that was it! How come he had even felt the necessity of painting them in these bright enamels? What was wrong with their own colour? Their selfcolour? What was wrong with that, their self colour, the colour of their selves? Had that also been done to create a distance? [...] It could even relate to field-theory, the whole thing, the sound and the number, insofar as such a theory ever managed to appear in relation to the lives of ordinary individuals, the manner in which each person, each organism, related to things as a totality, that old business of harmony, linked in the universal chain. And how in the name of fuck did the two guys with cudgels relate to that! Stuck fast in the mud, the miring quicksand - like the wee dog. Belabouring each other with those stout sticks. That magnetic force - an enactment? between the men just? or did Goya himself have a physical part in it? And what the hell did it matter anyway. This was him off with the concepts once again. Theoretical webs, dirty webs, fusty webs; old and shrivelling away into nothingness, a fine dust. Who needs that kind of stuff. Far far better getting out into the open air and doing it, actually doing it, something solid and concrete and unconceptualisable. (p. 9-10)

In the above passage apposite reference is made to the work of the Spanish artist Francisco de Goya, whose own career ended in the despair of the Pinturas negras or Black Paintings, murals painted on the internal walls of his own home. Goya's art spans the revolutionary period of the late eighteenth century and into the nineteenth and his final haunted works signal not only a crisis of faith in Enlightenment reason and but also an implacable disillusion with the hopes of social change also undertaken in the name of progress as a supposedly reformist alternative to the existing order in both Spain and France. The abject monstrosity of Goya's pathologically introverted last paintings signal his pessimism that old horrors will intensify rather than dissipate. The illumination of art can only paradoxically shed light on the darkness which engulfs it. Kelman 
makes explicit reference to Duelo a garrotazos or Duel with Clubs from the Black Paintings, which depicts two men mired in mud battering each other with cudgels. Goya's two figures locked in eternal, self-destructive combat is inserted here at the moment that Doyle deliberates that it is the burden of the Enlightenment and of art to inflict a violence on things in reducing them to the strictures of a totality of conceptual relationships which effect the particularity and truth of the pipes in their material singularity. Instead of reason, illumination or progress there is stagnation and the subordination of the object, of the non-identity of the world, to the deadening sameness of a brutally instrumental rationality.

Kelman's take on Goya's Duelo a garrotazos is then despondently extended to history and he deploys it to structure Patrick's despair at his brother Gavin's racist attitudes which surface when discussing a child who has been knocked down by a man from Pakistan:

What is the connection between being a man who is a Pakistani who has knocked down the wee boy who is now in intensive care o brother that the relationship includes you and me and your kids plus Nicola and the existence of maw and da and the ancestors, erupting their way out of the sewage system, when some form of fucking enlightenment, some form of fucking enlightenment.

Let's us just for fuck sake go up and visit the wee boy in intensive care and then go and visit the guy that was driving the car that knocked him down: let us just do that as a beginning. Me and you o brother ya bastard except that we cannot talk, as a beginning. Let us talk. Even just as a beginning. What is that. There isni a beginning. There is no beginning. You cannot discover a beginning. No beginning exists. There aren't any at all. There are two blokes in quicksand with cudgels belaying each other. There are two blokes one of whom is the ignorant Gavin Doyle from Cadder man and the other is the ignorant man who may or may not be from Pakistan (p. 305).

History is not progress but a stalled dialectic that has ossified in internecine violence and racism. The collective purpose of the class struggle and its solidarities collapse into atomized, directionless conflict without structure or resolution. The fact that Doyle imagines his family emerging from the sewage system (a sharply selected example of civilization's achievements!) transmits a Beckettian, excremental view of history that returns its reformist intent to an elemental reality beneath its surface motors. Notably, in this passage Enlightenment tails off syntactically in the gapped sentence and paragraph which hesitates unresolved with "some form of fucking enlightenment". And this parataxis, this gap in the syntax of thought, itself discloses a sense that the Enlightenment 
has not fulfilled its own rational ends. The very repetition of the phrase "some fucking enlightenment" coupled with its paratactic inconclusiveness collapse the teleology of progressive reason in on itself so that it is only ever the depleted repetition of its own instrumental, self-sustaining logic. Given that A Disaffection is the one novel by Kelman which so brims with the Romanticism that seems to shape his own vision of art and the artist, then it would appear that culture is offered as the only means by which the stalled, repetitive nightmares of enlightened modernity and progressive reason can be transcended or escaped. This reading of A Disaffection is most viable in the moment where Doyle tells the story of the pipes to Gavin's children who are watching the television:

I want to tell ye a story. It's about a pair of magical pipes [...] So what actually happened was this: I was round the back of this building, down a very dark and shadowy lane, an eerie and dank-smelling lane with high moss-covered dykes that kept out the light, where owls were hooting and cats miaowing in a very controlled but semi-scary way; you should've heard these damn owls and cats my fine friends! [...]

naw, no kidding ye, it was quite scary; I mind at one minute I happened to look up, and there I saw this little grey cat stalking along the very top of the highest wall, its round eyes glistening by the glare of the moon high up there with its old pockmarked face going back thousands and thousands of years, and this cat, its hairs all bristling like thin wee jaggy spikes [...]

and for one quiet, very very quiet and drawn-out, long, long, solitary solitary majestic moment in time, I thought like running, running fast, running away fast, getting away quick, quick quick quick $[\ldots]$

so what I did, I just bent down and lifted one up, because do you know this weans, I had a sudden wee think to myself that I wanted to play a tune $[\ldots]$ it was an urge, like a magic spell had befallen me. It was as if these two pipes themselves were calling out to me to come and play me come on and play me, so I lifted one up and what I did I just, okay, blew into it, and out came this long and deep sound that made me think of scores of and scores of years, and generations and generations and generations of people all down through the ages, and this tune - not exactly a tune, more of a sound, the one kind of long sound that you could occasionally pause from doing, then start again as if ye hadni stopped at all except when you came to the very end of it you would know about the pauses you did, they would all be a part of it. It was really really beautiful weans and it made me think of magic. I'm no kidding ye on. Magic. These pipes had something special about them and it was a magical something. (p. 298-299) 
Doyle's discovery of art arrests the normal flow of time and historical inevitability. The pipes provide a magic which provokes a form of yearning that seems to traverse history and momentarily solve or at least suspend its fractures. Doyle's "solitary" moment also transcends its own reclusion since by telling Gavin and his family this story both the pipes and Doyle's narrative about them have connected with others and transformed them too. It is not only generations hailed from some historical repository but also Doyle's own fractious family who are brought to share the transfiguring power of art. Here then is a kind of neo-Romantic faith that out of despair art may redeem, that out of the darkness comes illumination in the unexpected, particular and redemptive way in which aesthetic singularity erupts. In this interpretation the aesthetic imagination does finally grant reconciliation in sublime transcendence that is otherwise absent in Doyle's social circumstances. However, the fact that the dark scene at the back of the arts centre in which Doyle finds his salvational pipes is thronged with owls and cats also alludes to a work by Goya; and though the trace of Goya here is much less explicit than the other references in $A$ Disaffection this resonance helps complicate a straightforward reading of the novel as proposing that society's fissures can be circumvented by the pure release of art. The work in question by Goya is Plate 43 from his Caprichos, the etching El sueño de la razón produce monstruos. The title of this work encapsulates its visual ambivalences. In English, it can be rendered - depending on how you wish to understand El sueño - as either "The sleep of reason brings forth monsters" or "The dream of reason brings forth monsters". ${ }^{8}$ The etching itself depicts a sleeping or cowering, belaboured thinker at his writing desk besieged by a rabble of owls, cats and bats against a dark backdrop (and the inscription El sueño de la razón produce monstruos is scrawled on the philosopher's table). This image is either a potent manifesto for the Enlightenment or the most searing derogation of its contradictions. If the etching confronts us with the nightmare of what happens when reason sleeps and lets down its guard then it is clear that the Enlightenment and culture are what save us from barbarism. Plate 43 is thus a cautionary image which terrifies us with what art keeps at bay. Conversely, if the image directs us to consider that it is exactly the dream of reason which brings forth monstrosity - in other words, that the Enlightenment is an illusionary myth which is

8. For more, see in particular John J. Ciofalo's "Goya's Enlightenment Protagonist: A Quixotic Dreamer of Reason", Eighteenth-Century Studies, n 30.4, 1997, p. 421-436. Also useful are Paul Ilie's "Goya's Teratology and the Critique of Reason", Eighteenth Century Studies, n 18, 1984, p. 35-56; and John Dowling's, "The Crisis of the Spanish Enlightenment: Capricho 43 and Goya's Second Portrait of Jovellanos", Eighteenth Century Studies, n 18, 1985, p. 331-359. 
grounded in the violence and suffering caused by its pathological reason and self-legitimation - then this etching is actually a stark adumbration of twentieth-century critiques of the Enlightenment's contradictory effects such as Adorno and Horkheimer's. Goya's image is then a fitting work with which to haunt Doyle's artistic awakening in A Disaffection since it retracts the utopian purism of Lyotard and the postmodern Sublime and retains a much more ambivalent awareness that art is torn violently in conflicting directions by its promise of redeeming a sullied world and its simultaneous implication in the inequalities of that same world which falls short of redemption.

Therefore, Patrick Doyle's own phrase - "some fucking enlightenment" - can be read as rhetorical dismissal: i.e., "some fucking enlightenment that was". But, equally, it can also function as an expression of yearning, of a need for some fucking enlightenment. And the syntactic gap after this phrase can then also serve to presage that incomplete, unreconciled requirement; it can express a restive demand that there still be truths. So A Disaffection shoulders a melancholy knowledge: rather than give up on reason or truth for the lure of a sublime aesthetic beyond representation, this novel still harnesses "bloody truth" and "some fucking enlightenment" instead of pushing any truth content into a neoRomanticism transcendence of politics and society. While the bloody truth and the fucking enlightenment refuse their conscription by the absolute categories and conceptual totalities of Enlightenment rationality (and the violence done in the name thereof), they also ground a situated knowledge which knows not only its own limitations but also its own exigency. In contrast to the postmodern Sublime or the New Aestheticism, $A$ Disaffection permits the awareness that just because art is not homologous with society this does not mean that art is homologous with itself. Where the Enlightenment sought to reconcile subject and object in its rational bind, the current Neo-Romanticism of Thomas Docherty and others appears to have given up on the world and wishes instead to reconcile art with itself, to reconcile an aesthetic subject in its own aesthetic object (art's singularity) while at the same time quarantining society in its defiled, consumerist standardization of itself. By contrast, the melancholy knowledge of A Disaffection cannot find in art the transcendence of the degradation of the social since the escape supposedly offered by art is already socially mediated by the world's constitutive inequalities which make both society and art possible in their current forms. It is not only consumer culture that would feign to distract us; so too aesthetic purism would forget the suffering which helps brings art into being even as art promises to assuage it. As Adorno puts it: 
The abundance of real suffering tolerates no forgetting [...] Yet this suffering, what Hegel called consciousness of adversity, also demands the continued existence of art while it prohibits it; it is now virtually in art alone that suffering can still find its own voice, consolation, without immediately being betrayed by it. ("Commitment", p. 188)

Furthermore, Kelman's use of Goya's Black Paintings and their intimations of a harrowed modernity are especially germane in view of Adorno's comment:

To survive reality at its most extreme and grim, artworks that do not want to sell themselves as consolation must equate themselves with that reality. Radical art today is synonymous with dark art; its primary colour is black. (Aesthetic Theory, p. 39)

A Disaffection retains a commitment to the potentialities of art but it is an art that sheds light on its own darkening by the injustices of the world in which it is made, injustices which the melancholy truth of art's protectorate cannot betray without betraying itself.

\section{Bibliography}

Adorno T. W., Aesthetic Theory, trans. Robert Hullot-Kentor, London, Continuum, 2002.

Adorno T. W., "Commitment", Aesthetics and Politics, London, New Left Books, 1977, p. 177-195.

Adorno T. W., "Parataxis: On Hölderlin's Late Poetry", Notes to Literature, vol. 2, Rolf Tiedermann (ed.), trans. Shierry Weber Nicholsen, New York, Columbia U.P., 1992, p. 109-149.

Adorno T. W., Prisms, trans. Samuel and Shierry Weber, London, Nevill Spearman, 1967.

Adorno T. W. and Horkheimer Max, Dialectic of Enlightenment [1944], trans. John Cumming, London, Verso, 1997.

Barthes Roland. Mythologies, trans. Annette Lavers, London, Vintage, 1993.

GiofaloJohn J., "Goya's Enlightenment Protagonist: A. Quixotic Dreamer of Reason", Eighteenth-Century Studies, n 30.4, 1997, p. 421-436.

Docherty Thomas, Aesthetic Democracy, Stanford, Stanford U.P., 2006.

Dowling John, "The Crisis of the Spanish Enlightenment: Capricho 43 and Goya's Second Portrait of Jovellanos", Eighteenth Century Studies, $n^{\circ} 18,1985$, p. 331-359. 
Foucault Michel, Power / Knowledge: Selected Interviews and Other Writings 1972-1977, trans. Colin Gordon, John Mepham and Kate Soper, Brighton, Harvester Wheatsheaf, 1980.

Heidegger Martin, An Introduction to Metaphysics, trans. Ralph Manheim, New Haven, Yale U.P., 1959.

Heidegger Martin, Poetry, Language, Thought, trans. A. Hofstader, New York, Harper, 1971.

ILIE Paul, "Goya's Teratology and the Critique of Reason", Eighteenth Century Studies, n 18, 1984, p. 35-56.

JoughinJohnJ. and MaLPas Simon (eds), TheNewAestheticism, Manchester, Manchester U.P., 2003.

Kelman James, A Disaffection, London, Secker and Warburg, 1989.

Kelman James, Some Recent Attacks: Essays Cultural and Political, Stirling, AK Press, 1992.

Kenner Hugh, Foyce's Voices, London, Faber, 1978.

Lacoue-LabarThe Phillippe and Nancy Jean-Luc, The Literary Absolute: The Theory of Literature in German Romanticism, trans. Philip Bernard and Cheryl Lester, Albany, State U. of New York P., 1988.

Lyotard Jean-François, The Differend: Phases in Dispute, trans. George Van Den Abbeele, Manchester, Manchester U.P., 1988.

Lyotard Jean-François, The Postmodern Condition: A Report on Knowledge, trans. Geoff Bennington and Brian Massumi, Manchester, Manchester U.P., 1988.

Rancière Jacques, The Future of the Image, trans. Gregory Elliott, London, Verso, 2007. 